\title{
Effects of Laser Therapy on Experimental Wound Healing Using Oxidized Regenerated Cellulose Hemostat
}

\author{
LÍVIA PRATES SOARES, M.Sci., ${ }^{1}$ MARÍLIA GERHARDT DE OLIVEIRA, Ph.D., ${ }^{2}$ \\ ANTÔNIO LUIZ BARBOSA PINHEIRO, Ph.D., ${ }^{1}$ BRUNA RODRIGUES FRONZA, Ph.D., ${ }^{2}$ \\ and MARCONI EDUARDO SOUZA MACIEL, M.Sci. ${ }^{2}$
}

\begin{abstract}
Objective: The aim of this paper was to evaluate if the healing of wound sites containing oxidized regenerated cellulose hemostat can be optimized by laser therapy. Background Data: Topical hemostatic agents may be used to control bleeding in a variety of surgical sites. Hemostatic oxidized regenerated cellulose can cause strange body reactions and formation of granulomas. Materials and Methods: Thirty-six male Wistar rats averaging 6 wk of age, weighing $250 \mathrm{~g}$ each, were anesthetized had a standard $0.5-\mathrm{cm}^{2}$ block of oxidized regenerated cellulose (Surgicel ${ }^{\mathrm{TM}}$ ) inserted into an incision on the back of the tongue. Postoperatively the animals were randomly divided into two groups of 18 animals each: one was irradiated and one was not irradiated (control). In the treatment group, transmucosal laser therapy was applied in one area (Ga-Al-As laser, $4 \mathrm{~J} / \mathrm{cm}^{2}$, $\lambda=685 \mathrm{~nm}, 35 \mathrm{~mW}, \phi=0.06 \mathrm{~mm}$ ) and consisted of four sessions, with one session carried out every $48 \mathrm{~h}$. The animals were killed at three different times: G1 (1 d), G2 $(3 \mathrm{~d})$, and G3 $(7 \mathrm{~d})$. Tissues were stained with hematoxylin and eosin and then analyzed. Results: It was observed that the treated group exhibited a greater reduction in edema and inflammatory infiltrate. Conclusions: These results suggest that laser therapy at 685 nm could improve the healing process, even when the inflammatory process has been stimulated by oxidized regenerated cellulose hemostat.
\end{abstract}

\section{INTRODUCTION}

$\mathbf{T}$ The biocompatibility of cellulose and its derivatives is well established, ${ }^{1}$ although there are many reports of tissue reactions due to inflammation, foreign body reactions, and granuloma formation due to hemostatic oxidized regenerated cellulose. $^{2}$ It is also reported that most patients present with discomfort and pain after surgery. ${ }^{3}$ Bjorenson et al. ${ }^{4}$ reported that Surgicel ${ }^{\mathrm{TM}}$ is one of the most widely used hemostatics, and that it also induces the most inflammatory reactions.

Subcutaneously implanted cellulose sponges induce rapid growth of granulation tissue, which may fill the entire sponge. ${ }^{5}$ In a comparative study using different types of hemostatic agents, Mattsson et al. ${ }^{6}$ found that healing of mandibular bone

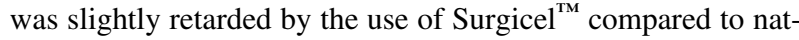
ural healing.
Experimental research with laser therapy shows that improvements in wound healing are caused by increased cellular proliferation. The photochemical changes stimulated by the action of laser energy occur in the cellular membranes and in the nuclei of cells, causing augmentation of local vasodilatation, angiogenesis, increased fibroblast production and collagen synthesis, production of $\mathrm{T}$ and $\mathrm{B}$ lymphocytes, release of endorphins, and local changes in prostaglandin. Laser therapy has been used to promote soft tissue healing, as an anti-inflammatory agent, and for pain relief, and also stimulates the immune system, thus reducing infectious effects. $^{7,8}$

The aim of this study was to evaluate, by morphologic analysis, the inflammatory and repair process in the presence of hemostatic oxidized regenerated cellulose and the effects of laser treatment on healing.

${ }^{1}$ Laser Center, Faculty of Dentistry, Federal University of Bahia (UFBA), Salvador, and ${ }^{2}$ Oral and Maxillofacial Surgery Department, Pontiff University Catholic of Rio Grande do Sul, Porto Alegre, Brazil. 
Table 1. Results of the Analysis of Hyperemia, Edema, and Neutrophils in the Experimental Groups

\begin{tabular}{|c|c|c|c|c|c|c|c|}
\hline & \multirow[b]{2}{*}{ Group } & \multicolumn{2}{|c|}{ Hyperemia } & \multicolumn{2}{|c|}{ Edema } & \multicolumn{2}{|c|}{ Neutrophil infiltration } \\
\hline & & Mean $\pm S D$ & $\mathrm{p}$ & Mean $\pm S D$ & $\mathrm{p}$ & Mean $\pm S D$ & $\mathrm{p}$ \\
\hline \multirow[t]{2}{*}{ First day } & Control & $2.50 \pm 0.54$ & \multirow[t]{2}{*}{$0.0101^{\mathrm{a}}$} & $2.83 \pm 0.40$ & \multirow[t]{2}{*}{$0.0001^{\mathrm{a}}$} & $2.83 \pm 0.40$ & \multirow[t]{2}{*}{$0.0007^{\mathrm{a}}$} \\
\hline & Irradiated & $1.50 \pm 0.54$ & & $1.17 \pm 0.40$ & & $1.50 \pm 0.54$ & \\
\hline \multirow[t]{2}{*}{ Third day } & Control & $1.83 \pm 0.40$ & \multirow[t]{2}{*}{$0.0015^{\mathrm{a}}$} & $2.00 \pm 0.63$ & \multirow[t]{2}{*}{$0.0014^{\mathrm{a}}$} & $0.66 \pm 0.51$ & \multirow[t]{2}{*}{1.0000} \\
\hline & Irradiated & $0.66 \pm 0.51$ & & $0.50 \pm 0.54$ & & $0.66 \pm 0.81$ & \\
\hline \multirow[t]{2}{*}{ Seventh day } & Control & $0.66 \pm 0.51$ & \multirow[t]{2}{*}{0.0924} & $1.50 \pm 0.54$ & \multirow[t]{2}{*}{$0.0007^{\mathrm{a}}$} & $0.50 \pm 0.55$ & \multirow[t]{2}{*}{$0.0493^{\mathrm{a}}$} \\
\hline & Irradiated & $0.16 \pm 0.40$ & & $0.16 \pm 0.40$ & & $0.00 \pm 0.00$ & \\
\hline
\end{tabular}

${ }^{\mathrm{a}} p<0.05$.

\section{MATERIALS AND METHODS}

The animals used were 36 male adult albino rats (Rattus norvegicus albinus). The rats were healthy and weighed approximately $250 \mathrm{~g}$ each. All the rats were kept, fed, and handled identically. With the approval of the Committee of Ethics in Research, the experiment was performed in the Laboratory of Experimental Surgery of the State Foundation of Production and Research in Health-RS-Brazil. The animals were anesthetized with Zoletil ${ }^{\circledR}$ and subjected to surgery. In the back of the tongue one standardized fragment, $0.5 \mathrm{~cm}^{2}$ in size, of oxidized regenerated cellulose (Surgicel $^{\mathrm{TM}}$; Johnson \& Johnson, Piscataway, NJ, USA) was inserted into a small incision. The wounds were sutured closed with 6-0 nylon.

The rats were randomly divided into two groups. In the control group, the cellulose was implanted in the wound site and left otherwise untreated. The laser-treated group received the cellulose implant and post-surgery the wounds were irradiated with $4 \mathrm{~J} / \mathrm{cm}^{2}$. The laser device used was a continuous-wave GaAl-As light-emitting diode at $685 \mathrm{~nm}$ with an output of $30 \mathrm{~mW}$ (Thera Lase/DMC Equipamentos Ltda., São Carlos, SP, Brazil). To determine the applied dose of energy, the spot size was measured and the energy density and power output were determined

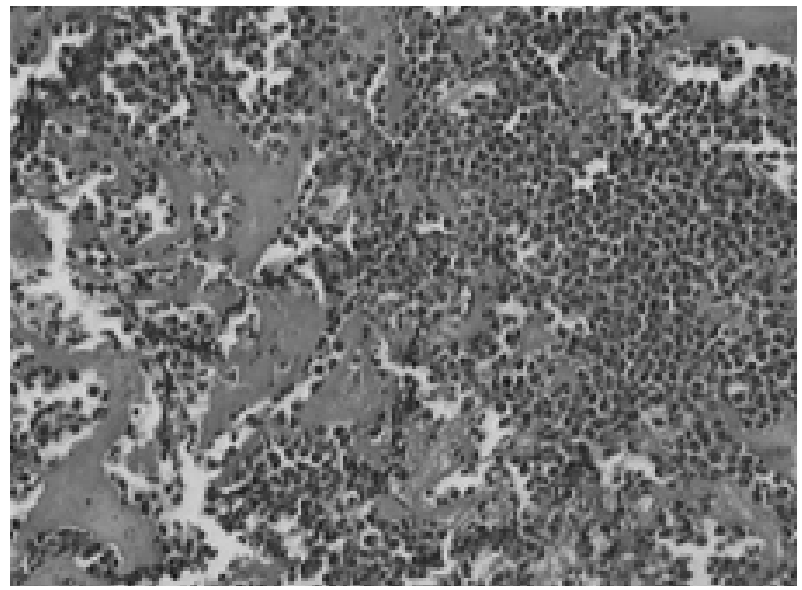

FIG. 1. Photomicrograph of a tissue sample from an animal in the control group 3 days post-surgery. Inflammatory infiltrate cells, blood clotting, and surgical trabeculae can be seen (H\&E, original magnification $100 \times$ ). according to the Tuner-Hode equation. ${ }^{9}$ The laser probe was applied to a single point, in contact with the wound. The applications were repeated every $48 \mathrm{~h}$ for up to $7 \mathrm{~d}$. Six animals from each group were killed at three time points: $1 \mathrm{~d}, 3 \mathrm{~d}$, and 7 d post-surgery.

Each biopsy sample included the entire tongue of the animal. The surgical parts were fixed in $10 \%$ formalin and embedded in paraffin. Histologic $5-\mu \mathrm{m}$ sections were cut and stained with hematoxylin and eosin, then the lamina were analyzed under light microscopy. The histologic alterations were semi-quantitatively evaluated on coded slides and classified as absent (0), mild (1), moderate (2), and marked (3), in accordance with protocols of previous studies. ${ }^{10,11}$

The differences between the control group and experimental groups were analyzed using the Student's $t$-test, and the level of significance was set at $p<0.05$.

\section{RESULTS}

Clinically, all the wounds in the mucosa of the tongue healed by first intention and without apparent infection.



FIG. 2. Photomicrograph of a tissue sample from an animal in the irradiated group 3 days post-surgery. Fewer inflammatory infiltrate cells and surgical trabeculae and less blood clotting are seen here than in the control group sample (H\&E, original magnification $100 \times$ ). 


\section{Descriptive analysis}

During the 7-d experimental period, an acute inflammatory infiltrate and significant edema were evident in the control group, and in the laser treatment group these changes were less apparent. The progress of hyperemia was also enhanced by the laser therapy.

\section{Statistical analysis}

Statistically significant differences between the control and laser groups were found with regard to hyperemia on the first and the third days post-surgery $(p=0.0101$ and $p=0.0015$, respectively). There was more hyperemia seen in the control group than in the laser group at those time points; however, by the seventh day there was no longer any statistically significant difference between the groups.

There was significantly less edema in the irradiated group at all three time points studied. There were more neutrophils seen in the control group than in the irradiated group, and it reached statistical significance on the first and seventh days post-surgery ( $p=0.0007$ and $p=0.0493$, respectively) (Table 1 ).

Three days after insertion of the cellulose, the number of inflammatory cells was statistically higher in the control group (Figs. 1 and 2), but and on the seventh day there was no statistically significant difference between the groups.

\section{DISCUSSION}

Previous studies have shown that Surgicel ${ }^{\mathrm{TM}}$ is an efficient hemostatic. Because of its low cost and easy availability it is widely used in hospitals. ${ }^{12,13}$ The oxidized regenerated cellulose acts as an artificial clot and it adheres to wound edges, hastening healing of surgical wounds. ${ }^{14,15}$

However, it has been associated with severe inflammatory and foreign body reactions, as well as with granuloma formation. ${ }^{16,17}$ The hemostatic cellulose used in this study did not cause any foreign body reaction or suture dehiscence, despite these phenomena having been reported in previous studies. ${ }^{18}$

Tissue healing is a complex process that involves both local and systemic responses. The process of wound healing involves several types of cells, enzymes, growth factors, and other substances. The application of laser energy to wound healing has been shown to be effective in modulating both the local and systemic responses. In soft tissues, with the proper wavelength, dose, and local conditions, laser therapy has an anti-inflammatory effect, reduces pain, and accelerates cell proliferation, and consequently speeds the healing process. $8,18,19$

Although the clinical efficacy of low-level laser therapy has been proven in controlled studies, ${ }^{11}$ little is known about histologic alterations that may occur due to its use, particularly those associated with use of an exogenous biomaterial. Due to its biomodulating effects on tissues, laser therapy may promote tissue healing and reduce the inflammation produced by the cellulose used in this study.

In our study, we used $4 \mathrm{~J} / \mathrm{cm}^{2}$ of laser energy for each session, ${ }^{20}$ because this energy density was previously found to promote a favorable tissue response.

Due to its rich blood supply, severe hemorrhage may occur with surgery on the maxillofacial region. Also in this region, some blood vessels run in neurovascular bundles, and some researchers have reported negative effects of oxidized regenerated cellulose on peripheral nerve function. ${ }^{21,22}$

We found that laser therapy reduced hyperemia and edema in areas of cellulose implantation compared to that seen in the control group. These findings are significant, because exacerbation of edema in the early stages of healing may modify its normal course, and reduction of hyperemia reduces the likelihood of postoperative hemorrhage. These facts indicate that laser treatment may improve the action of the local hemostatic. The acute inflammatory response was also positively influenced by laser therapy, suggesting improvement in tissue reactions to oxidized regenerated cellulose.

\section{CONCLUSION}

In our study we concluded that the Ga-Al-As laser, operating within the parameters described above, induced biomodulation of healing in the presence of oxidized regenerated cellulose (Surgicel). These results suggest that laser therapy may hasten healing when used in conjunction with a cellulose hemostatic.

\section{REFERENCES}

1. Fricain, J.C., Granja, P.L., Barbosa, M.A., de Jéso, B., Barthe, N., and Baquey, C. (2002). Cellulose phosphates as biomaterials. In vivo biocompatibility studies. Biomaterials. 23, 971-980.

2. Gao, H.W., Lin, C.K., Yu, C.P., Yu, M.S., and Chen, A. (2002). Oxidized cellulose (Surgicel) granuloma mimicking a primary ovarian tumor. Int J Gynecol Pathol. 21, 422-423.

3. Petersen, J.K., Krogsgaard, J., Nielsen, K.M., and Norgaard, E.B. (1984). A comparison between 2 absorbable hemostatic agents: gelatin sponge (Spongostan) and oxidized regenerated cellulose (Surgicel). Int J Oral Surg. 13, 406-410.

4. Bjorenson, J.E., Grove, H.F., List, N.G., Haash, G.C., and Austing, B.P. (1986). Effects of hemostatic agents on the $\mathrm{pH}$ of body fluids. J Endodont. 12, 289-292.

5. Ekholm, E., Tommila, M., Forsback, A., et al. (2005). Hydroxyapatite coating of cellulose sponges does not improve its osteogenic potency in rat bone. Acta Biomaterialia. 1, 535-544.

6. Mattsson, T., Anneroth, G., Köndell, P.A., and Nordenram, A. (1990). ACP and Surgicel in bone hemostasis. A comparative experimental and histologic study. Swed Dent J. 14, 57-62.

7. Franks, Y. (1999). Low level laser therapy. J Commun Nurs Surv. 13, 14-22.

8. Brugnera, Jr. A., and Pinheiro, A.L.B. (1998). Lasers na odontologia moderna. São Paulo: Pancast, 1998.

9. Tuner, J., and Hode, L. (1998). It's all in the parameters: a clinical analysis of some well-known negative studies on low-level laser therapy. J Clin Laser Med Surg. 16, 245-248.

10. Bisht, D., Gupta, S.C., Misra, V., Mital, V.P., and Sharma, P. (1994). Effect of low intensity laser radiation on healing of open wounds in rats. Indian J Med Res. 100, 43-46.

11. Pugliese, L.S., Medrado, A.P., Reis, S.R.A., and Andrade, Z.A. (2003). The influence of low-level laser therapy on modulation of collagen and elastic fibres. Pesq Odontol Bras. 17, 307-313.

12. Halfpenny, W., Fraser, J.S., and Adlam, D.M. (2001). Comparison of 2 hemostatic agents for the prevention of postextraction hemorrhage in patients on anticoagulants. Oral Radiol Endod. 92, 257-259. 
13. Wagner, W.R., Pachence, J.M., Ristich, J., and Johnson, P.C. (1997). Comparative in vitro analysis of topical hemostatic agents. J Surg Res. 66, 100-108.

14. Alpaslan, C., Alpaslan, G.H., and Oygur, T. (1997). Tissue reaction to three subcutaneously implanted local hemostatic agents. $\mathrm{Br}$ J Oral Maxillofac Surg. 35, 129-132.

15. Essential product information. Surgicel, Surgicel Fibrillar and Surgicel Nu-Knit absorbable hemostats (oxidized regenerated cellulose). Piscataway, NJ, Johnson \& Johnson, (http://www.jnjgateway.com/public/USENG/SURGICEL_FIBRILLAR_Labeling_Inf ormation.pdf accessed June 10, 2007).

16. Buckley, S.C., and Broome, J.C. (1995). A foreign body reaction to Surgicel mimicking an abscess or tumor recurrence. $\mathrm{Br} \mathrm{J} \mathrm{Neu-}$ rosurg. 9, 561-563.

17. Ito, H., Onishi, H., and Shoin, K. (1989). Granuloma caused by oxidized cellulose following craniotomy. Acta Neurochir. 100, $70-73$.

18. Finn, M.D., Schow, S.R., and Schneiderman, E.D. (1992). Osseous regeneration in the presence of four common hemostatic agents. $\mathrm{J}$ Oral Maxillofac Surg. 50, 608-612.

19. Silva Júnior, A.N., Pinheiro, A.L.B., Oliveira, M.G., Weismann, R., Ramalho, L.M.P., and Nicolau, R.A. (2002). Computerized morphometric assessment of the effect of low-level laser therapy on bone repair: an experimental animal study. J Clin Laser Med Surg. 20, 83-87.

20. Mester, E., Spiry, T., and Szende, B. (1971). Effect of laser rays on wound healing. Am J Surg. 122, 532-535.

21. Alkan, A., Inal, S., Yildirim, M., Bas, B., and Agar, E. (2007). The effects of hemostatic agents on peripheral nerve function: an experimental study. J Oral Maxillofac Surg. 65, 630-634.

22. Loescher, A.R., and Robinson, P.P. (1998). The effect of surgical medicaments on peripheral nerve function. Br J Oral Maxillofac Surg. 36, 327-332.

Address reprint requests to: Dr. Lívia Prates Soares, M.Sci. Universidade Federal da Bahia Faculdade de Odontologia Av. Araújo Pinho no. 62 Canela Salvador, BA, Brasil, CEP 40110-150

E-mail: liviaps@oi.com.br 